\title{
Henry A. Jones (1889-1981)
}

\author{
P.W. Simon ${ }^{1}$ \\ U.S. Department of Agriculture, Agricultural Research Service, Vegetable Crops Research Unit, Department of \\ Horticulture, University of Wisconsin, Madison, WI 53706
}

W.H. Gabelman ${ }^{2}$

Department of Horticulture, University of Wisconsin, Madison, WI 53706

D.F. Franklin ${ }^{3}$

Department of Horticulture, University of Idaho Research and Extension Center, Parma, ID 83660

\begin{abstract}
Henry A. Jones was one of the great pioneers in agriculture. He is most widely remembered for his original research on the genetics of cytoplasmic-genic male sterility in onions and consequent development of methods to apply this discovery for the production of $F_{1}$ hybrid seed, which has been useful in a wide range of horticultural and agronomic crops. His revelation, study, and application of cytoplasmic-genic male sterility tied together the creative insight of scientific discovery to the successful application of a basic biological phenomenon in a way rarely accomplished in agriculture. In 1925 he first discovered (in a single bulb of the 'Italian Red' onion cultivar) what he proved to be cytoplasmic-genic male sterility; by 1944 he developed 'California Hybrid Red No. 1' (Fig. 1), the first hybrid in any crop based on the use of cytoplasmic-genic male sterility; today, a significant proportion of the onions in the world are hybrids using cytoplasmic-genic male sterility. Moreover, similar systems of male sterility have since been used in producing hybrids of other crops, including carrots, beets, petunias, maize, sorghum, rice, wheat, and many others. Without the pioneering research of Jones, the advantages of cytoplasmic male sterility would have likely gone unrecognized for some time. Because of their vigor and uniformity, hybrid crop cultivars are familiar to not only scientists, but to the general public as well. Yet, hybrids are only feasible for a limited number of crops without the method of cytoplasmic-genie male sterility discovered and put into use in onion by Jones. T.W. Whitaker (1983) aptly stated that, "Dr. Jones' discovery of a self-sterile onion bulb in 1925 was the origin of a major revolution in agriculture and the seed industry."
\end{abstract}

Jones was born in 1889 in Deer Park, Ill., and grew up helping his family with market

Received for publication 3 June 1991. Research supported by USDA/ARS, and College of Agriculture and Life Sciences, Univ. of WisconsinMadison.

${ }^{1}$ Research Geneticist and Professor.

${ }^{2}$ Professor

${ }^{3}$ Research Professor Emeritus.

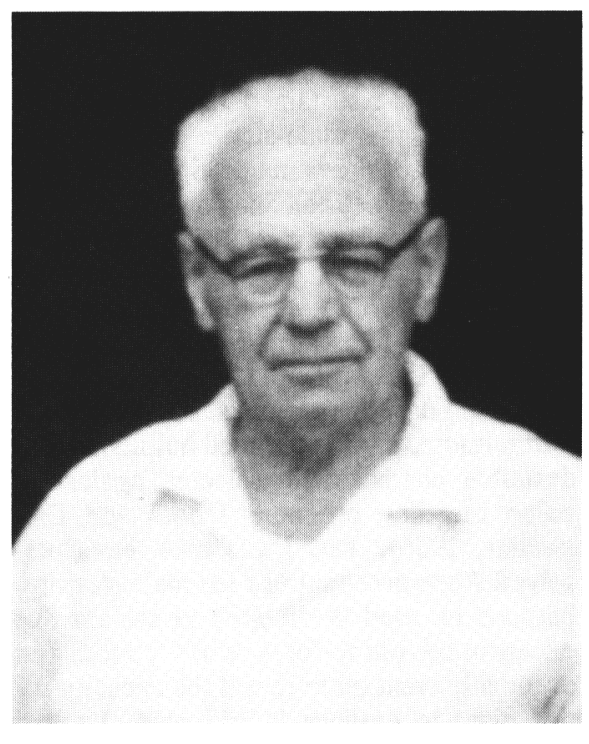

followed by 2 years as professor of vegetable gardening at the Univ. of Maryland. While in West Virginia, he began research for his first publication (Jones, 1920). This work was completed in Maryland and dealt with a problem familiar to him since his youthonion dormancy. During his last summer at Maryland, Jones recruited Victor Boswell as a graduate student. Although the duration of their relationship was brief, Boswell received an indelible impression of Jones as a remarkably versatile botanist and botanical illustrator; a man of few, but very well-chosen, words; and a well-trained, competitive boxer. Jones had high expectations of those who worked with him, yet years later he did not expect his subordinates and colleagues to perform certain routine tasks. For example, he insisted on filling seed packets of his onion breeding lines for distribution to his cooperators, since he felt they were a significant reflection of himself (V. Boswell, personal communication). With Boswell, Jones initiated his first research on onion reproductive biology at Maryland (Jones and Boswell, 1922).

In 1922, Jones accepted an invitation to direct the Division of Truck Crops at the Univ. of California, Davis, as associate professor. He developed a broad program studying the morphology, reproductive biology, and disease resistance of vegetable crops with J.T. Rosa. Resulting from this cooperation was the classic text "Truck Crop Plants" (Jones and Rosa, 1928). Some of the original studies of onion, asparagus, lettuce, carrot, peas, brassica, cauliflower, beet, and snapdragon(!) also came from this program, as did a small group of graduate students, many of whom went on to make outstanding contributions to horticulture on their own. These students include S.L. Emsweller, G.C. Hanna, Helen (nee Monosmith) Pearson, O.H. Pearson, and T.W. Whitaker.

It was during his years from 1922 to 1936 at UC-Davis that Jones made his key discoveries and initial observations on cytoplasmic-genic male sterility. Although the developments from this important work with onion are probably most often remembered by students today, it is interesting to note that, through 1932, 15 of his 20 bulletins and 


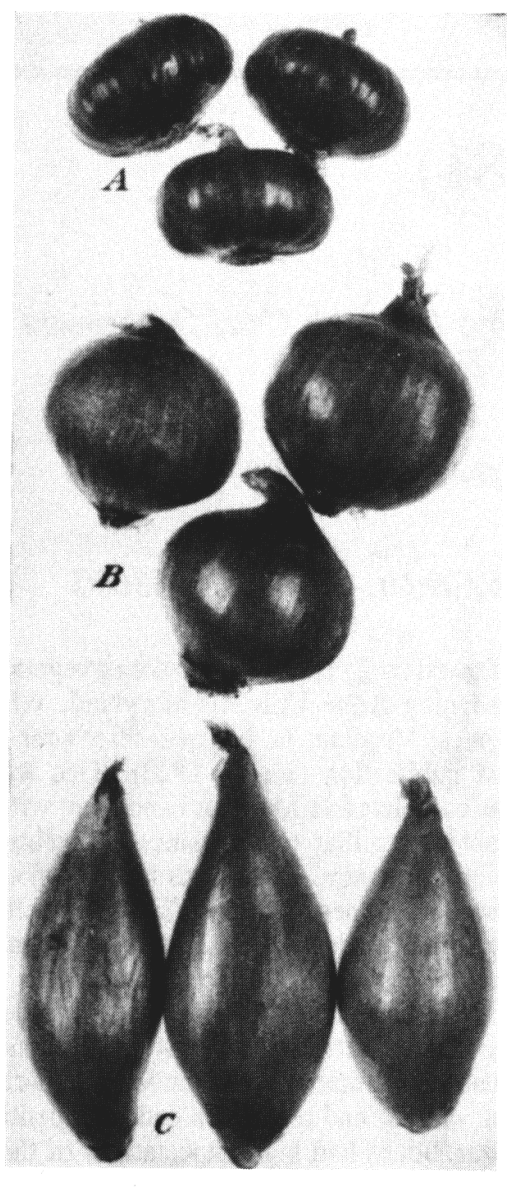

Fig. 1. California Hybrid Red No. 1 Onion (B), the first hybrid in any crop developed using cytoplasmic-genie male sterility, and its two-component inbred parents, Lord Howe Island (A), and male-sterile Italian Red (C).

refereed papers dealt with crops other than onion-lettuce (e.g., Jones, 1927; Jones and Tavemetti, 1932) and, especially, asparagus (e.g., Jones, 1932; Jones and Robbins, 1924, 1926, 1928; Robbins and Jones, 1925, 1926). The first three papers of his career dealt with onions and reported work completed before or soon after he arrived in California. Two of these three papers dealt with onion reproductive biology. His next two onion papers dealt with seed (Jones, 1927) and bulb (Jones, 1929) production. Even though asparagus production stands out as at least equal to his onion breeding efforts in publications through 1932, Jones stated that his own efforts had been "devoted chiefly to onion breeding" in his 1932 American Society for Horticultural Science Presidential Address (Jones, 1932). This fact was emphatically documented by 10 more onion breeding papers before he left UC-Davis, and only three more papers on other crops. Thus, there was no question that onion breeding was his major emphasis. Included in these onion breeding papers were three important publications documenting the Allium fistulosum $\mathrm{x}$ A. cepa interspecific hybrid, one of which was published in Science (Emsweller and Jones, 1935a-c).

Another interesting point surfaces in the account of onion breeding presented by Jones in his ASHS Presidential Address. He contrasted his selection for vigor and uniformity with mass selection in onion with the ability to create vigorous and uniform $F_{1}$ hybrids in corn by emasculation (detasselling). He stated somewhat ruefully that, in onion, "obviously the same technique cannot be used as with corn, because it is impracticable to emasculate large numbers of flowers" (Jones, 1932). This statement suggests that, although he found the ultimate source of onion male sterility in 1925, work by Jones and his students by 1932 did not suggest a definitive system to create $F_{1}$ hybrids in onion on demand. Low seed set kept population sizes too small to determine the mode of inheritance. It was not until about 1936 that enough $\mathrm{F}_{1}$ hybrid onion seed was produced to start trial evaluations and begin assessing inheritance patterns. Thus, scientific curiosity is thought to have sustained Jones' interest in maintaining the male-sterile onion (O.H. Pearson, personal communication). This was, however, a very strong and unusual curiosity for a man who was, by all accounts, very practical.

The male-sterile 'Italian Red' onion plant, designated 13-53, was undesirable in several ways (Fig. 2). A plant failing to bear seed in a breeding program is usually discarded. Furthermore, 13-53 produced bulbils, an undesirable characteristic selected against in onion breeding programs (Jones and Emsweller, 1936). Yet, Jones must have perceived some potential use for male sterility, because he used the bulbils to sustain this exceptional plant for several years, and eventually went on to reveal the capacity for this plant to produce hybrid seed. He had observed the uniformity, but loss of vigor, on inbreeding as well as striking heterosis in hybrid onions produced by hand emascula-

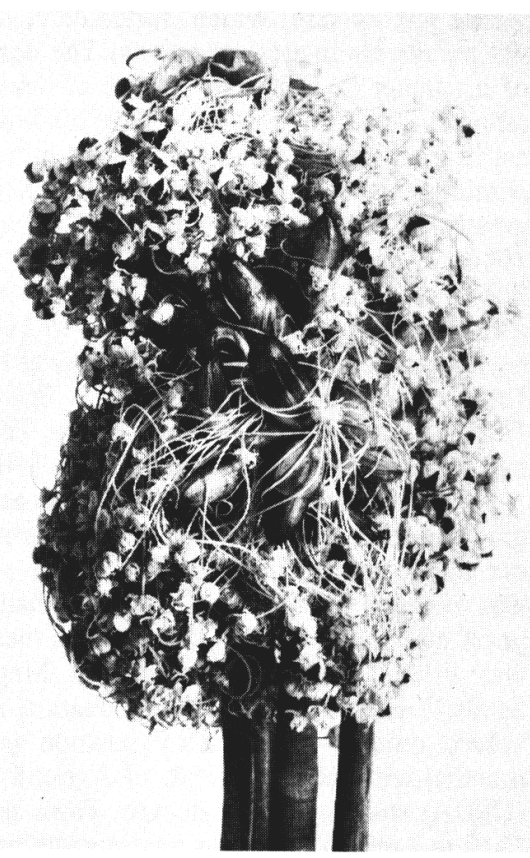

Fig. 2. An umbel of onion Italian Red 13-53 with both bulbils and seed. tion (Jones and Emsweller, 1933; Jones, 1937), and he had developed systems for rearing and using insect pollinators (Jones and Emsweller, 1934). He had evaluated methods for improving seed set, and studied onion productive biology. History does not reveal the level of planning and extent of searching that went into the discovery of 'Italian Red 13-53'; thus, the details of events surrounding this exceptional discovery and the creative insight to apply male sterility go unrecorded. The consequences of this event, fortunately, are well-documented and we continue to reap their benefits.

In 1936, Jones left California to take charge of the USDA onion and potato investigations in Beltsville, Md. It is here that he took the basic information he generated on onion male sterility to develop the hybrid seed production techniques we use today. He continued to publish, primarily on onion breeding, to yield 32 more onion papers and bulletins and five more on other crops before his last publication, the classic "Onions and their Allies" in 1963, with L.K. Mann. His important contributions to spinach breeding are included in these works (Jones et al., 1956). Yet, the 1943 paper describing the inheritance of onion genie-cytoplasmic male sterility, 18 years after its discovery, stands as the classic of Jones' career (Jones and Clarke, 1943). As discussed by Gabelman (Janick, 1989), this paper documents the genetic basis of the system used to economically and reliably produce $F_{1}$ hybrid seed, first in onion and later in a wide range of crops. Without a reliable genetic basis to condition male sterility predictably, hybrid cultivars would only be used in a few crops. Furthermore, the subtleties of this system are unlikely to have been used without the foresight, diligence, and hard work of Jones to prove that this system worked biologically and could be handled by a seed trade familiar only with open-pollinated cultivars. Fortunately, the use of this system was not stifled by a patent. Jones saw the national scope of a USDA program as necessary to make hybrid onions successful. Other male-sterile onions have been sought and found, but the 'Italian Red 13-53' accounts for most, if not all, of the onion genie-cytoplasmic male sterility currently in use. Work continuing today interestingly indicates that the male-sterile cytoplasm in onion may well be that of a species other than Allium cepa (X. Havey, personal communication).

In addition to his research talents, Jones was an excellent organizer and leader. $\mathrm{He}$ initiated an exemplary, broad-based cooperative program to develop, test, and release onions across the United States, and he oversaw the development of a similar program in potatoes. As a leader of the National Onion Breeding Program, he established a unique network of collaborators, which served two primary purposes. First, cooperators across the country were able to remain current on the best production and storage practices and latest cultivars available because Jones traveled to the up to 22 testing sites across the country each year evaluating onion produc- 
tion and storage trials. Interaction with his cooperators was also a vital part of the success of this program. Although his classroom teaching skills were not highly regarded, his interaction with individuals and small groups was superb. Some of these cooperators were, or are, the leading onion breeders-testing the best germplasm available at the time and developing even better material in their programs (Figs. 3 and 4). These included E.W. Davis and G. McCollum (Idaho), W.C. Edmundson (Colorado), D.F. Franklin (Idaho), W.H. Gabelman (Wisconsin), A.E. Kehr (Iowa), and H. Munger (New York). Second, Henry Jones was able to use the network of cooperators to see that the hybrid onion technique was in fact working as planned; that seed producers were able to use his new, more-complicated method of seed production effectively with acceptable seed yields, and hybrids were as uniform in fullscale production as they were in small test plots. Thus, Jones was able to successfully transfer the technology for commercial seed production to the seed industry and the technology and strategies for developing onion hybrids to both public and private onion breeders. He developed more than 50 onion hybrids for use across North America, several of which are still in production today. The onion hybrids developed by Jones were used not only in North American production areas, but also in several major foreign onion-growing districts. In addition to the increased yield, uniformity, and more-stable productivity imparted by the hybrid onions he developed, improved resistance to diseases and pests, including downy mildew (Jones et al., 1939), smut (Walker et al., 1944), smudge (Jones et al., 1946), thrips (Jones et al., 1934), and particularly pink root (Porter and Jones, 1933; Perry and Jones, 1955; Jones and Perry, 1956), was incorporated into inbreds and hybrids he developed. With these accomplishments and 39 years of public service, Jones was not yet ready to retire at age 68 . In 1957, he left the USDA/ARS and became director of research for the Desert Seed Co., El Centro, Calif. $\mathrm{He}$ deliberated at great length to reach this decision, but, in the end, chose to move to a position where he could see the application of his discovery on the largest possible scale. He spent 22 productive years in industry, and thus covered the full picture of science and technology first-hand from discovery to description to field testing to full-scale commercial production.

We can enthusiastically agree with Jones, who said "I am indeed glad that those numb fingers and cold feet in boyhood did not forever keep me away from onions" (Jones, 1944). He was fortunate to be able to see the complete development of a curiosity with some vague possibilities to a very widely used technique of commerce (Fig. 5). He served as President of ASHS in 1932, and received numerous awards recognizing his accomplishments, including the Vaughan Award in 1943 from ASHS for his paper with A.E. Clarke (Jones and Clarke, 1943), the Herbert Medal in 1944 from the Amer-

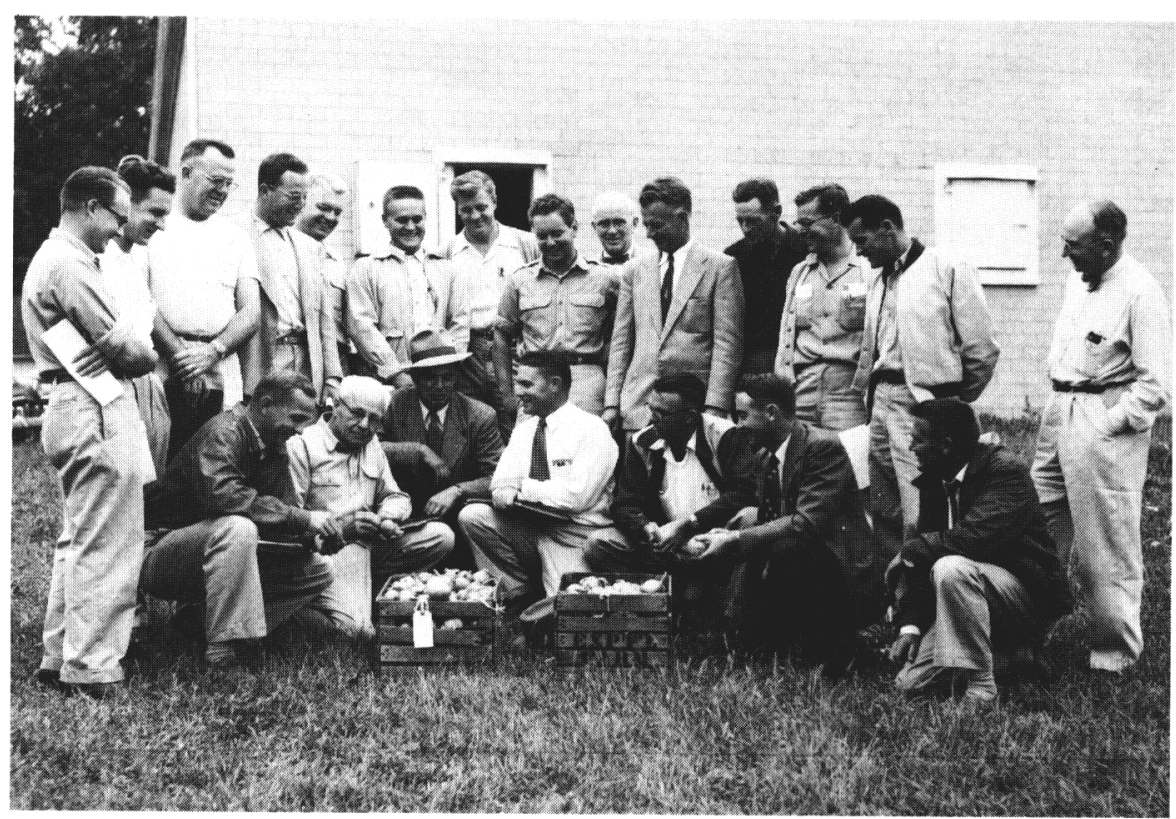

Fig. 3. Henry Jones and cooperators at Hybrid Onion Field Day, Michigan State College Muck Farm, 16 Sept. 1954. Front row (left to right): W. Gabelman, Univ. of Wisconsin; H. Jones, U.S. Dept. of Agriculture; E. Owen, Ferry-Morse Seed Co.; C. Peterson, Michigan State College; D. Franklin, Univ. of Idaho; R. Lucas, Michigan State College; and W. Scott, Joseph Harris Seed Co. Standing (left to right): P. Bessey, Michigan State College; S. Wittwer, Michigan State College; P. Olesen, Crookham Seed Co.; S. Ries, Michigan State College; A. Kehr, Iowa State College; J. Weigle, Michigan State College; H. Tiessen, Michigan State College; L. Rappaport, Michigan State College; R. Marshall, Michigan State College; R. Carolus, Michigan State College; K. Trapp, Trapp Bros., Beulah, Mich.; J. Lingle, Michigan State College; B. McDonald, Crookham Seed Co.; and F. Davis, Michigan State College.

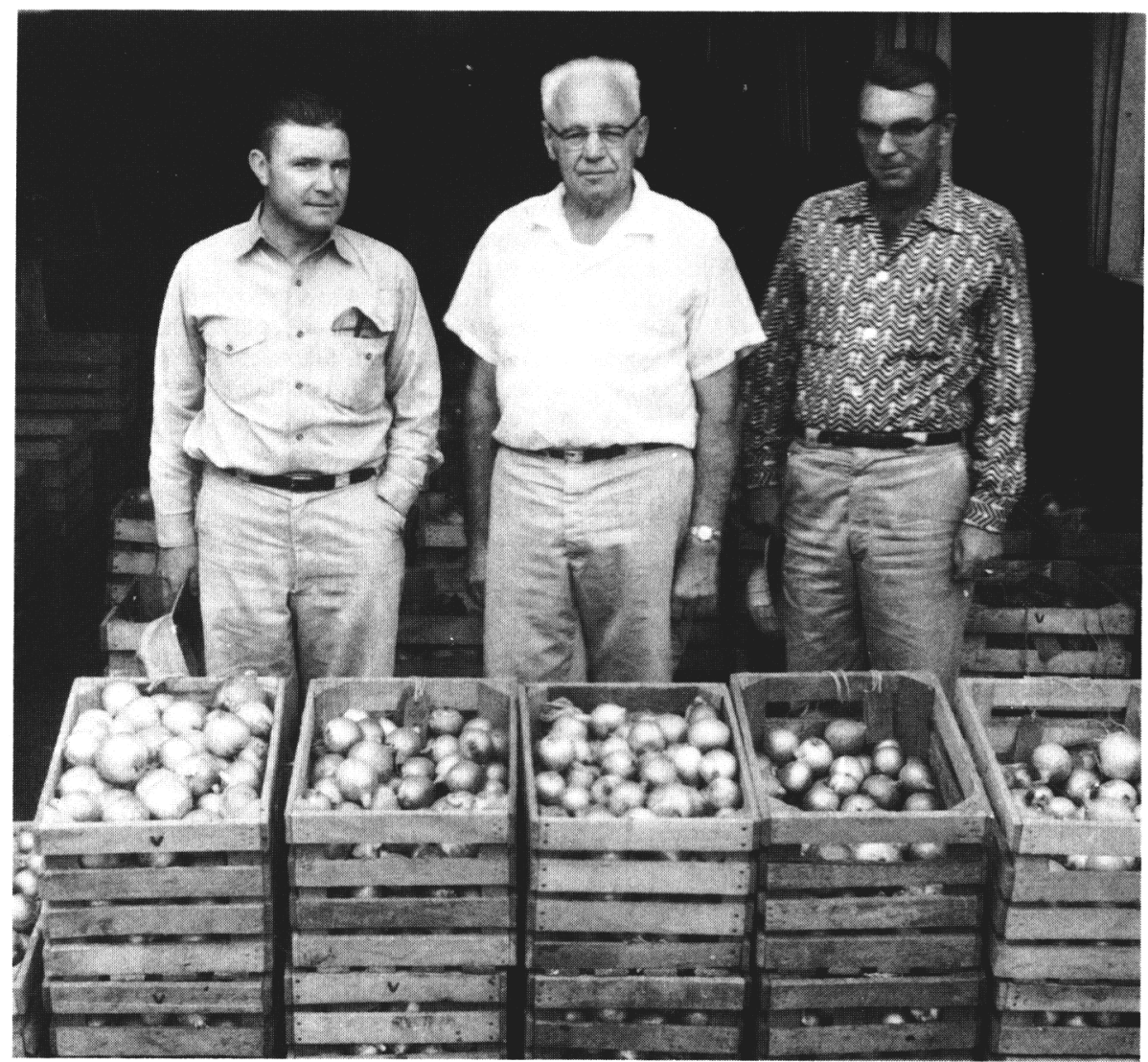

Fig. 4. Henry Jones (center) and cooperators C.E. Peterson (left) and D.F. Franklin (right). 


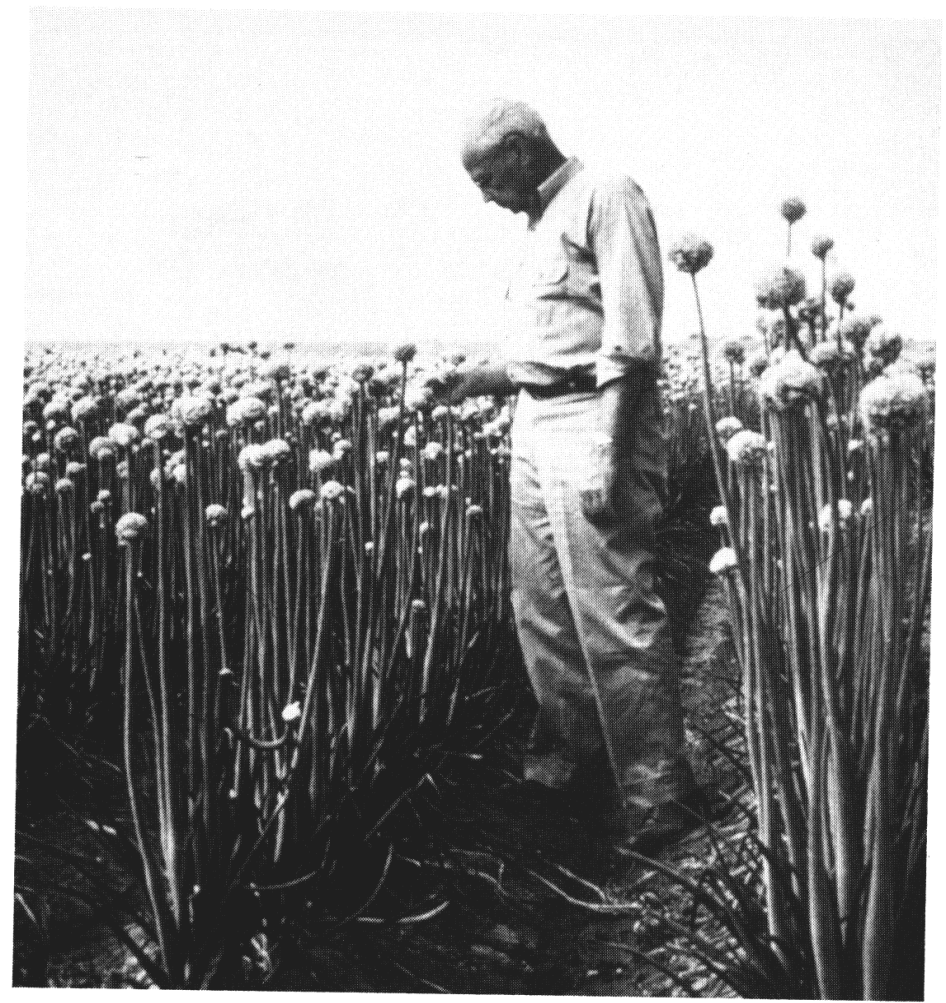

Fig. 5. Jones evaluating onion flowers.

ican Plant Life Society, an honorary DS in 1952 from the Univ. of Nebraska, and the USDA Distinguished Service Award in 1953.

Henry A. Jones was a wise, considerate, humble man with great vision and tenacity. He embodied the characteristics of seeking, finding, and applying knowledge of horticulture, and science in general, for our greater good. He is a most fitting member for the Horticulture Hall of Fame.

\section{Literature Cited}

Emsweller, S.L. and H.A. Jones. 1935a. An interspecific hybrid in Allium. Hilgardia 9:265273.

Emsweller, S.L. and H.A. Jones. 1935b. A gene for control of interstitial localization of chiasmata in Allium fistulosum L. Science (n.s.) 81:543-544.

Emsweller, S.L. and H.A. Jones. 1935c. Meiosis in Allium fistulosum, Allium cepa, and their hybrid. Hilgardia 9:277-294.

Janick, J. (ed.). 1989. Classic papers in horticultural science. Prentice Hall, Englewood Cliffs, N.J.

Jones, H.A. 1920. Preliminary report on onion dormancy studies. Proc. Amer. Soc. Hort Sci. 17:128-133.
Jones, H.A. 1923. Pollination and self-fertility in the onion. Proc. Amer. Soc. Hort. Sci. 20:191197.

Jones, H.A. 1927. Pollination and life history studies of lettuce (Lactuca sativa L.). Hilgardia 2:425-479.

Jones, H.A. 1927. The influence of storage temperature on seed production in the Ebenezer onion. Proc. Amer. Soc. Hort. Sci. 24:61-63.

Jones, H.A. 1929. Spacing, time-of-planting and size-of-seedling studies with the California Early Red onion. Proc. Amer. Soc. Hort. Sci. 26:114118.

Jones, H.A. 1932. Spacing studies with male and female asparagus plants. Die Gartenbauwissenschaft. 6 .

Jones, H.A. 1932. Vegetable breeding at the University of California-Presidential address. Proc. Amer. Soc. Hort. Sci. 29:572-581.

Jones, H.A. 1937. Onion improvement. Breeding Vegetable Crops. USDA Yrbk Sep. 1581:233250.

Jones, H.A. 1944. An autobiography. Herbertia 11:35-36.

Jones, H-A., S.F. Bailey, and S.L. Emsweller. 1934. Thrips resistance in the onion. Hilgardia 8:215-232.

Jones, H.A. and V.R. Boswell. 1922. Time of flower primordia formation in the onion (Allium cepa L.). Proc. Amer. Soc. Hort. Sci. 19:144147.
Jones, H.A. and A.E. Clarke. 1943. Inheritance of male sterility in the onion and the production of hybrid seed. Proc. Amer. Soc. Hort. Sci. 43:189-194

Jones, H.A. and S.L. Emsweller. 1933. Methods of breeding onions. Hilgardia 7:625-642.

Jones, H.A. and S.L. Emsweller. 1934. The use of flies as onion pollinators. Proc. Amer. Soc. Hort. Sci. 31:160-164.

Jones, H.A. and S.L. Emsweller. 1936. A malesterile onion. Proc. Amer. Soc. Hort. Sci. 34:582-585.

Jones, H.A. and L.K. Mann. 1963. Onions and their allies. Interscience, New York.

Jones, H.A., D.M. McLean, and B.A. Perry. 1956. Breeding hybrid spinach resistant to mosaic and downy mildew. Proc. Amer. Soc. Hort. Sci. 68:304-308

Jones, H.A. and B.A. Perry. 1956. Inheritance of resistance to pink root in the onion. J. Hered. 47:33-34.

Jones, H.A., D.R. Porter, and L.D. Leach. 1939. Breeding for resistance to onion downy mildew caused by Peronospora destructor. Hilgardia 12:531-550.

Jones, H.A. and W.W. Robbins. 1924. Growing and handling asparagus crowns. Calif. Agr. Ext. Sta. Bul. 381

Jones, H.A. and W.W. Robbins. 1926. Influence of cutting asparagus the first year after planting on production the following year. Proc. Amer. Soc. Hort. Sci. 23:23-28.

Jones, H.A. and W.W. Robbins. 1928. The asparagus industry in California. Calif. Agr. Expt. Sta. Bul. 446

Jones, H.A. and J.T. Rosa. 1928. Truck crop plants. McGraw-Hill, New York.

Jones, H.A. and A.A. Tavernetti. 1932. The headlettuce industry of California. Calif. Agr. Ext. Circ. 60.

Jones, H.A. , J.C. Walker, T.M. Little, and R.H. Larsen. 1946. Relation of color inhibiting factor to smudge resistance in onions. J. Agr. Res. 72:259-264

Perry, B.A. and H.A. Jones. 1955. Performance of short-day, pink-root resistant varieties of onions in Southern Texas. Proc. Amer. Soc. Hort. Sci. 66:350-353.

Porter, D.R. and H.A. Jones. 1933. Resistance of some cultivated species of Allium to pink root (Phoma terrestris). Phytopathology 23:290-298.

Robbins, W.W. and H.A. Jones. 1925. Secondary sex characters in Asparagus officinalis L. Hilgardia 1:183-202.

Robbins, W.W. and H.A. Jones. 1926. Sex as a factor in growing asparagus. Proc. Amer. Soc. Hort. Sci. 23:19-23.

Walker, J.C., H.A. Jones, and A.E. Clarke. 1944. Smut resistance in an Allium species hybrid. J. Agr. Res. 69:1-8.

Walker, J.C., H.A. Jones, and A.E. Clarke. 1944. Onion set production. U.S. Dept. Agr. Farmer's Bul. 1955.

Whitaker, T.W. 1983. Dedication: Henry A. Jones (1889-1981) plant breeder extraordinaire. Plant Breeding Rev. 1:1-10. 